\title{
Concept of Majja Dhatu of Ayurveda in Perspective of Bone Marrow: A Review
}

\author{
Ritesh ${ }^{1}$, Manjry Anshumala Barla ${ }^{2}$, Rakesh Roushan *3. \\ ${ }^{1}$ M.D. Scholar, Kriya Sharir, CBPACS, New Delhi, India. \\ ${ }^{2}$ Senior Medical Officer (Ay.), Directorate Of Ayush, Govt. Of NCT Of Delhi. \\ ${ }^{* 3}$ Assistant Professor, Kriya Sharir, CBPACS, New Delhi, India.
}

\section{ABSTRACT}

\begin{abstract}
Ayurveda has described three basic physiological constituent dosha, dhatu and mala for the existence of human body. Among them, seven dhatus form the structural units of the body. The functions of dhatus are dharana (to support) and poshan (to nourish). Dhatus undergo continuous construction and degeneration to maintain a state of equilibrium of the body. Majjadhatu is the sixth dhatu to be formed after asthi dhatu in uttrottardhatuposhan cycle. Bone marrow can be considered as a part of majja dhatu playing a significant role in erythropoiesis. Acharya Sushrut has mentioned about saraktameda and majja. Asthi (bone) and sandhi (joints) are the foundation of majjavahasrotas. The quantity of majjadhatu is one anjali. This manuscript is an attempt to explore the physio-anatomy of majja dhatu based on physiological functions described in ayurveda classics. For which the basic material has been collected from the ancient classics with the available commentaries as well as text books of contemporary modern medical science.

KEY WORDS: Bone Marrow, Majja, Majjavahasrotas, Medas, Saraktameda.
\end{abstract}

Address for correspondence: Dr. Rakesh Roushan, Assistant Professor, Kriya Sharir, CBPACS, New Delhi, India. E-Mail: rakesh.roushan45@gov.in

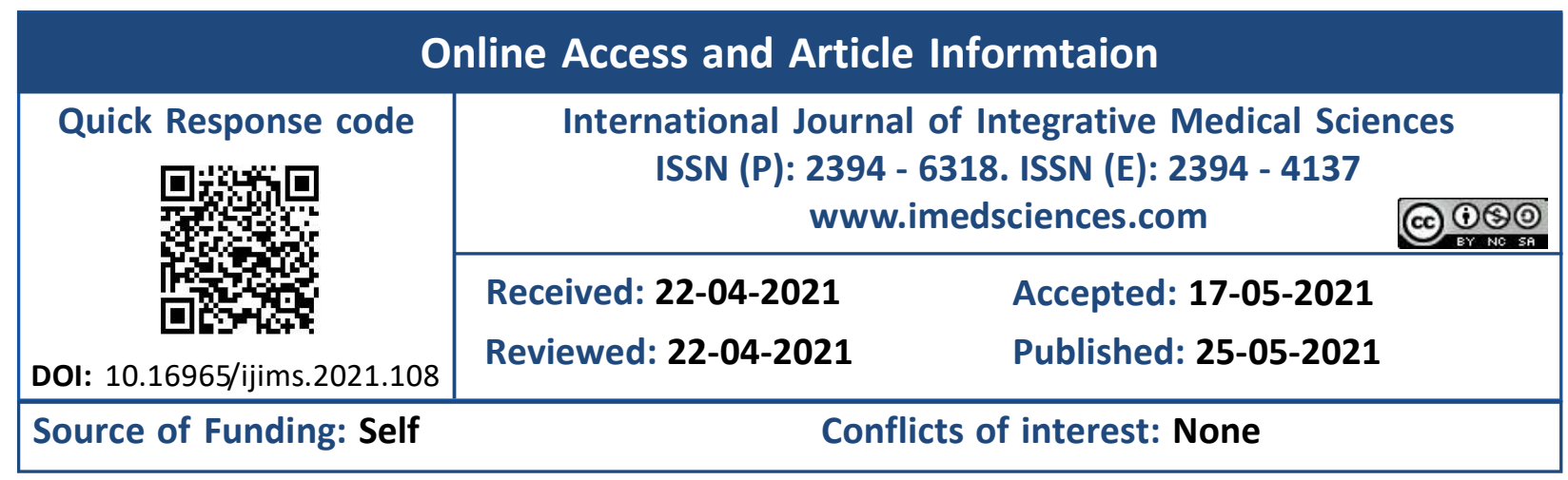

\section{INTRODUCTION}

In Ayurveda health is a status where the dosha, dhaatu, agni, mala, all the physiological process are in homeostatic state and soul, sense organ and mind are in a state of total wellbeing [1]. Out of them, Dhatus are seven in number. These are rasa (plasma), Rakta (formed blood cells), Mamsa (muscle tissues), Meda (fatty tissues), Asthi (bone tissue), Majja (bone marrow) and Shukra (reproductive tissues). In Ayurvedic classics, three laws have been explained for the formation, nourishment and replenishment of dhatus as dhatu poshannyaya. Ingested food material (Ahara) being digested by jathragni makes the final product known as ahara Rasa and kitta (waste product). The functions of ahara rasa tarpan (nourishment), vardhan (to increase), dharan (maintenance) and yapan (to give support in the old age) [2]. This ahara rasa undergo transformation with the help of Bhutagni and dhatvagni to nourish subsequent dhatus.

They just undergo continuous nourishment and replenishment [3]. Dhatvagni acts upon ahara rasa, sthayi dhatu and poshak dhatu amsa (precursor for next dhatu), updhatu and mala (the sthula entity) are formed and very sukshama entity mana, and ojas are nourished. Sthayi Posya dhatu (permanent) forms the structural architecture of body. Asthayi Posak dhatu (nutrient part) comprise of nutrients and forms the precursors of subsequent posya dhatu. Dhatu Poshaka Amsha nourishes one after 
another from Rasa dhatu to Sukra Dhatu. In this way the seven kinds of Poshak Ansha (Asthayi Dhatu) is transported to the respective Poshaya (Sthayi) Dhatu through their respective Srotas (channels) specific to each Sthayi Dhatu. Majja dhatu is the sixth dhatu to be nourished in sequence of dhatu poshan. Three principles are given for the continuous nourishment of dhatus i.e Kshiradadhi nyaya, Kedarikulya nyaya and khlekapot nyaya. These laws work together for the nourishment and replenishment of dhatus. Kshirdadhi nyaya works for the conversion of complex nutrients into simpler form and vice versa, while kedarikulya nyaya and khale kapota nyaya works for the continuous nourishment and replenishment of dhaatus. In kshiradadhi nyaya, Acharya Charak has mentioned rasagni act upon ahara rasa and convert it into posya rakta dhatu. Similarly, majjagni acts upon majja dhatu and convert it into posya majja dhatu [4]. Acharya Sushrut has mentioned rasdhatvagni acts upon ahara ras and three byproducts are formed sthula bhaga rasa, malabhag kapha and anu-rakta. Raktagni act upon anu rakta formed in the process of formation of rasa dhatu helps in the formation of rakta dhatu [5].

In the same way, majjagni act upon anu majja dhatu formed in the process of asthi dhatu formation helps in the formation of majja dhatu. Acharya Charak has mentioned vata produces pores to the surface of asthi dhatu and afterwards the hollow cavities inside the asthi dhatu which gets filled up by sneha of meda known as majja [6]. Vriddha Vagbhatta has mentioned, the third kala is medodhara kala present over abdomen and small bones. Medas present in the small bones turned into red. This can be termed as red bone marrow. This meda present inside the cranial bones is termed as mastulunga and when present in large bones is known as majja [7].

Acharya Gannanath Sen also classified majja as rakta majja (red bone marrow) and peeta majja (yellow bone marrow). In contemporary modern science, Bone marrow is encountered in the central cavities of long bones and is one of the largest organs of the body. Bone marrow comprised of up to $4-5 \%$ of the total body weight in humans. Bone marrow is a vibrant organ with incessant changes taking place with growing age and altered hematopoietic needs. It is composed of hematopoietic cell, marrow adipose tissue and supportive stromal cells. In adult human beings, bone marrow is mainly situated in the ribs, vertebrae, sternum and iliac bone. The blood cells instigate their lives in the bone marrow starting from a single type of cell called the pluripotential hematopoietic stem cell. All the cells of the circulating blood are eventually derived from the pluripotent hematopoietic stem cell. Stem cells constantly divide and produce new cells. Some new cells remain as stem cells and others go through a series of maturing stages as precursor before becoming mature blood cells. Stem cells rapidly multiply to make millions of blood cells each day. Multiple proteins called growth inducers control the growth and reproduction of the different stem cells.

The growth inducers promote only growth of the cells but not differentiation. Differentiation is the function of another set of proteins called differentiation inducers. Each of these differentiation inducers causes one type of committed stem cell to differentiate one or more steps toward a final adult blood cell. Factors outside the bone marrow control the formation of the growth inducers and differentiation inducers [8]. Majja dhatu mentioned in ayurvedic literature cannot be represented by a single entity. In modern era, students particularly first year of Bachelor of Ayurvedic Medicine and Surgery with background of Physics, Chemistry and Biology face a lot of problem in understanding the concept of Ayurveda. Ayurveda is the science based on the notion of functional understanding. Increased demand of Ayurveda science is required to have a deep understanding of Ayurvedic principles. The present article is aimed at retrospective description of the anatomical structures of majja dhatu based on its physiological functions and its relevance in context with contemporary science.

Development of Marrow Cavity: Majja is derived from the snehans of medo dhatu. Acharya Chakrapani has stated that the 
tissues which are formed during embryonic life are only nourished and replenished by Aahar Rasa during later phases of life. However, the portrayal of successive renovation of Rasa Dhatu to Shukra Dhatu may be understood as the chronological tissue differentiation during embryonic life as the totipotent cells of embryo get differentiated into tissue specific cells. During embryonic life, bone develops from the mesoderm. Bone formation in embryonic life is preceded by formation of a cartilaginous model. The process of bone formation is called ossification. In the process of development of long bones, a layer of periosteum lays down a layer of bone around the shaft of the cartilaginous model. This periosteal layer progressively extends to the whole length of the diaphysis. As more layers of bone are deposited over it so the periosteal bone becomes thicker.

However, it is not desirable for it to become thick. The osteoclasts come to line up the inner surface of the shaft. Osteoclasts take out the bone from inner surface of the shaft. Thus, the shaft grows in diameter and it does not become too thick. The osteoclasts also remove the trabeculae present in the centre of bone. Trabeculae are formed during the endochondral ossification. In this way, bone marrow cavity is formed. There is corresponding increase in the size of marrow cavity with the increase in the diameter of the shaft. This marrow cavity extends towards the end of diaphysis but does not reach the epiphyseal plate. The marrow cavity and spaces of spongy bones are filled by bone marrow. The bone marrow tissues are of two different types in adults i.e., red bone marrow and yellow bone marrow. The red bone marrow is present at the end of bone and is involved in formation of blood cells. Yellow bone marrow is present in the shaft of long bones and predominantly made of adipose tissue [9].

Acharya charak has stated vayu produces hollowness inside the asthi dhatu. These hollow cavities are filled by sneha (adipose tissue) of medo dhatu. This sneha deposited in the hollow cavities of bones is known as majja dhatu (bone marrow) [10]. Osteoclastic activity can be compared with the functions of vayu involved in the formation of bony cavity.

Replenishment and Nourishment of Majjja Dhatu: The ingested food materials are digested by the action of jatharagni, and converted into ahara ras and kitta. Ahara ras gets absorbed into blood vessels with help of smana vayu and reaches to the heart through portal vein. Heart forcefully ejects the poshaka ras through its twenty four dhamanies to whole body with the help of vyana vayu. The poshaka ras (circulating nutrients) present in the circulating blood are transformed in the tissues by the action of dhatvagni. In the sequence of mamsa dhatu formation, mamsadhatvagni acts upon poshak mamsa dhatu (vata, ambu, tejas) and sthyai mamsa dhatu is replenished and nourished. Medo-dhatu is formed by the action of medo-dhatvagni on the poshak medo dhatu and sthyai medo dhatu is replenished and nourished. Asthi dhatu is formed by the action of asthi-dhatvagni on the poshak asthi dhatu and sthyai asthi dhatu is replenished and nourished. Activity of vayu produces hollowness inside the asthi dhatu which get filled up by the sneha of medo dhatu known as majja dhatu.

\section{Location of Majja Dhatu and Bone Marrow:}

The third kala is known as medodhara kala, Medas is present in the abdomen and the small bones of living beings. The long bones contain bone marrow. The bone marrow is found especially inside the sthool asthi (large bones), and marrow found inside all other bones is known as sarakta medas. Part of medas present in the sthool asthi (large bones) is known as majja, which may be compared with the yellow bone marrow. Further, Acharya Sushruta has classified bones as sthula asthi and other then sthoolasthi. Acharya Dalhan has given the term alpa asthi for bones other then sthoolasthi. Majja (yellow bone marrow) is found especially (visheshtah) inside the sthula asthi (large bones) and sarakta medas (red bone marrow) is specifically present in alpa-asthi. Bony cavities are filled with sneha portion of medas. This medas has given different name as per the location of bony cavities. Acharya Vagbhatta has mentioned, medas present in 
the udara (abdomen) and anu asthi (small bones) of human beings is sarakta medas which may be compared with the red bone marrow, in large bones it is termed as majja, in cranial cavity termed as mustulunga (brain tissue) $)^{3}$. The moolstahna of majjavaha srotas are asthi and sandhi. Human skull has 8 cranial bones. These cranial bones are joined together by fixed and immovable joints and form a cranial cavity. The part of medas present in the cranial cavity is termed as mastulunga (brain tissue)[11]. This mastulunga extended downwards up to the vertebral column through spinal cord.

In prenatal life, bone marrow first develops in the clavicle toward the end of fetal maturity. It becomes active about three weeks later. Bone marrow takes over the liver as the major hematopoietic organ at 32 to 36 weeks of gestation. Bone marrow remains red until the age of seven years. The red bone marrow is gradually replaced by yellow fat tissue with advancing age. Adults have an average of about $2.6 \mathrm{~kg}$ of bone marrow, about half of which is red. In adults, the maximum concentration of red bone marrow is in the bones of the vertebrae, hip bone (ilium), breastbone (sternum), ribs, and skull. Central cavities of the long bones are filled with yellow bone marrow.

Composition: Bone marrow is composed of hematopoietic tissue and adipocytes. It is surrounded by vascular sinuses and interspersed inside the network of trabecular bone matrix. Bone marrow cavities can be trabecularized or nontrabecularized as per location in the body. Conventionally, two main types of bone marrow are differentiated: yellow bone marrow and red bone marrow. These two types of bone marrow have distinctive composition and vascularization. Yellow bone marrow contains abundant carotenoid bodies in its fat cells, is primarily composed of adipocytes. Chemical composition of yellow bone marrow is $80 \%$ fat, $15 \%$ water, and $5 \%$ protein. Yellow bone marrow vasculature is sparse, containing merely a few capillaries with continuous basement membrane. Red bone marrow is loaded in haemoglobin and erythrocytes. Red bone marrow is composed of both hematopoietic cells and fat cells. Its chemical composition can vary but typically contains $40-60 \%$ lipids, $30-40 \%$ water and 10-20\% protein. Red bone marrow is responsible for body blood cell production and highly vascular, carrying a vast network of sinusoids. Red bone marrow is present in the cavities of the skull, sternum, scapulae, vertebrae, ribs, pelvic bones.

\section{Conversion of Red Bone Marrow to Yeallow}

Bone Marrow: Red bone marrow continues to convert into yellow bone marrow as the age advances and continues throughout lifetime. This conversion follows a pattern from the peripheral towards the central skeleton, as described by Neumann already in 1882. Within an individual bone, conversion of red to yellow marrow occurs first in the epiphysis, then in diaphysis and lastly in metaphysis, following a distal to proximal pattern. The adult red and yellow marrow state is reached around the age of 20 years. After this age, red marrow is restricted to the axial skeleton (spine, sternum, ribs, pelvis, skull). The red to yellow bone marrow conversion in the axial skeleton continues throughout life and the resulting red marrow distributed over the entire skeleton is in general spatially heterogeneous. In addition, although the general assumption that all marrow adipocytes are equivalent. In 1976 Tavassoli suggested that red marrow adipocytes may possibly vary from yellow marrow adipocytes [12]. The pedestal of traditional categorization of bone marrow into yellow and red marrow compartments is the presence of hematopoietic cells.

\section{FUNCTIONS}

Snehana: Normal homeostatic condition of blood prevents the sign of Twaka parushyam and brings snigdhata in the body. In the arterial system, arterioles are the last small branches acting as control conduit, through which blood is released into the capillaries. Arterioles have the capability of vastly altering blood flow in each tissue in response to its need [13]. The function of the capillaries is to exchange fluid, electrolytes, nutrients, hormones, and other substances between the blood, extracellular fluid and skin. Acharya charak has explained four types of snehan 
dravya ghrita, taila, vasa and majja. In clinical practice majja is prescribed for snehana with the vehicle manda (scum of gruel) especially in the month of April (madhav). Majja, contains more than $80 \%$ of fat, after digestion it comes into circulation in adequate quantity, develops the features of proper oleation as explained in snehadhaya of charak samhita.

Bala: The supreme essence of the dhatus beginning from rasa dhatu to sukra dhatu is known as ojas. Its presence is important for all the vital activities. Ojas and bala works in cause and effect relationship; Ojas is the cause and bala is its effect [14]. Ojas may be compared to the immunity. Immunity provides strength against the invading pathogens and toxins. Immunity is the capacity to resist almost all types of toxins or foreign organisms that have a propensity to damage the tissues and organs of the body. Much of immunity is acquired immunity. Basically two types of acquired immunity occur in the body i.e. cell-mediated immunity and humoral immunity. T lymphocytes are responsible for forming the activated lymphocytes providing cell-mediated immunity. The B lymphocytes are responsible for forming antibodies that provide humoral immunity. Common lymphoid progenitor cell is found in the bone marrow which is the precursor of both $T$ and $B$ lymphocytes. When specific antigens come in contact with $T$ and $B$ lymphocytes in the lymphoid tissue, the $T$ lymphocytes form activated $T$ cells and the $B$ lymphocytes produces gamma globulin antibodies at an extremely rapid rate of about 2000 molecules/ second for each plasma cell. The activated $T$ cells and antibodies react exclusively against the particular types of antigens. There by providing a rapid and potent defense against infectious agents [15]. Bone marrow is the precursor of both $\mathrm{T}$ and $\mathrm{B}$ lymphocytes. These lymphocytes provide immunity and ultimately bala among the individuals.

Shukrpushti: There is a sequential process of dhatu nourishment and replenishment called as uttrotardhatuposhan nyaya. Acharya Chakrapaani has postulated kedari kulya Nayaya (blood vessels supplying nutrients to the tissues), rakta gets nourished first by its homologous nutrient fraction present in the rasa dhatu in succeeding manner. In the same way, shukra dhatu is replenished and nourished after majja dhatu. Acharya Dalhana has postulated, precursor of succedding dhatu is formed by the previous dhatu. In the formation of majja dhatu, sukshma shukra is formed and shukraagni acts on it which nourishes and replenishes (Shukrpushti) the shukra dhatu.

Asthi puran: Acharya charak has stated vayu produces hollowness inside the asthi dhatu. These hollow cavities are filled by sneha (adipose tissue) of medo dhatu. The sneha deposited in the hollow cavities of bones is known as majja dhatu (bone marrow) [16].

Osteoclasts remove the bone from internal shell of the shaft. Thus, the shaft grows in diameter and it does not become too thick. The osteoclasts also remove the trabeculae present in the centre of bone. In this way, bone marrow cavity is formed. Asthi purana function of the majja dhatu is mainly due to its location in the marrow cavity.

\section{DISCUSSION}

In human body dosha, dhatu, mala and agni, are the basic regulatory systems to maintain the homeostasis. Dhatus are seven in number and plays an important role for sustenance of life. Dhatus are nourished by their specific channels and Dhatvagni. The roles of Dhatuvaha Srotas and Dhatvagni in tissue formation and nutrition have been explained by Dhatu Poshana Nyaya. These nyayas are Ksheer Dadhi Nyaya, Kedari Kulya Nyaya, Khale Kapota Nyaya, Ek Kala Dhatu Poshana Nyaya. Aacharya charak has stated that the tissues are nourished and replenished in a sequential manner beginning from the Ras Dhatu to the Shukra Dhatu by their own specific dhatwagni. The supreme essence of the all dhatus is known as ojas. Ojas and bala have cause and effect relationship. Ojas is the cause and bala is its effect. Bala of an individual can also be assessed by saara pareeksha. Rasa gets converted to Rakta, similarly Rakta becomes Mamsa, Mamsa into Meda, Meda into Asthi, Asthi into Majja, and Majja into Shukra. Majjadhatu is the sixth dhatu to be formed 
after asthi dhatu in uttrottardhatu-utpati sequence. Bone marrow can be correlated as a part of majja dhatu playing a significant role in erythropoiesis. Acharya Sushrut has mentioned saraktameda is present inside the all bones of anuasthi and majja is present especially inside the large bones. Acharya Charak has mentioned vata produces pores to the surface of asthi dhatu and afterwards the hollow cavities inside the asthi dhatu which gets filled up by fatty tissue known as majja. The moolstahna of majjavaha srotas are asthi and sandhi. Acharya Vagbhatta has stated, the third kala is medodhara kala present over abdomen and small bones.

Medas present in the small bones are sarakta medas. This can be termed as red bone marrow. This meda present inside the asthi sandhi (cranial cavity formed by the fixed joints of cranial bones) termed as mastulunga (central Nervous System) and when present in large bones is known as majja [17]. Acharya gannanath sen also classified majja as rakta majja (red bone marrow) and peeta majja (yellow bone marrow). The quantity of majjadhatu is one anjali. Red bone marrow is involved in hemopoiesis, where all blood cells are formed. In this function, the bone marrow constitutes a specific niche, harboring many different cell types-mainly hemopoietic stem cells and progenitor cells. Common lymphoid progenitor cell is found in the bone marrow which is the precursor of both $T$ and $B$ lymphocytes. The activated $T$ cells and antibodies react highly specifically against the particular types of antigens. There by providing a rapid and potent defense against infectious agents and provide immunity and resistance against invading pathogens. This can be compared with the bala action of majja dhatu. Asthi purana function of the majja dhatu is mainly due to its location in the bony cavity. Majja dhatu helps in Shukrpushti (nourishment and replenishment) of shukra dhatu. The research conducted in Germany raises the future possibility of developing immature sperm cells from human bone marrow[17].

The breakthrough manufacturing sperm that can be used in IVF treatment or to restore fertility to men made sterile by cancer therapy. Such applications are still many years away, but scientists hope to grow fully formed sperm cells in near future from bone marrow [17].

\section{CONCLUSION}

On the basis of above discussion it is summarized that Ayurveda has given a scientific insight on majja dhatu. The description of Majja dhatu in ayurveda is relevant in present scenario. The functions of Bone marrow can be correlated with that of majja dhatu playing a significant role in erythropoiesis and immunity. It has been also reported that researches raises the future possibility of developing immature sperm cells from human bone marrow. This concept has great implication of the Shukrpushti (nourishment and replenishment) function of majja dhatu. Hence the concept of majja dhatu in ayurvedic sciences signifies its relevance with the contemporary modern physiology of bone marrow.

\section{REFERENCES}

[1]. Ritesh D, Roushan DR. A Critical Appraisal on Digestive System (Avastha Paka) of Ayurveda in the Modern Physiological Perspective. Sch Int J Anat Physiol. 2020;3(8):72-6.

[2]. Dalhan Doshadhatumalmuliya adhyaya. In: Yadav T,editor. (Reprint ed.). Nibhandhasagraha on Sushruta Samhita. Varanasi: Chaukhambha Sanskrit Sansthana;2010.

[3]. Agrawal S, Verma V, Gehlot S. Explication on tissue nutrition in prenatal and postnatal life: An Ayurveda perspective. J Ayurveda Integr Med [Internet]. 2020;(xxxx). Available from: https:// doi.org/10.1016/j.jaim.2020.05.002

[4]. Chakrapani. Grahani Chikitsa adhyaya. In: Gaur BL, editors. Ayurveda deepika on Charak Samhita. 1st ed. New Delhi (India): Rastriya ayurveda vidyapeeth; 2014. p. 796-875.

[5]. Dalhan. Sonita varnaniya adhyaya. In: Prasad BB, editors. Nibandha Sangraha on Sushrut Samhita. Revised edition. New Delhi (India): Rastriya ayurveda vidyapeeth; 2002. p.133-146.

[6]. Chakrapani. Grahani Chikitsa adhyaya. In: Gaur BL, editors. Ayurveda deepika on Charak Samhita. 1st ed. New Delhi (India): Rastriya ayurveda vidyapeeth; 2014. p. 812-816.

[7]. Vaghbhatta. Angvibhagiya Adhyaya. In: Gupta AD, editors. Astanga Sangraha. Revised edition. Varanasi (India): Chaukambha Krishnadas Academy; 2016. p. 301.

[8]. Moharana P, Roushan R. RANJAK PITTA AND ITS AFFILIATES IN MODERN PERSPECTIVE/ : A REVIEW. 2019;10(3):124-30. 
[9]. Singh, I. (2014). Human Embryology. JP Medical Ltd. Formation of tissues of the body 182-184.

[10]. Chakrapani. Grahani Chikitsa adhyaya. In: Gaur BL, editors. Ayurveda deepika on Charak Samhita. 1st ed. New Delhi (India): Rastriya ayurveda vidyapeeth; 2014. p. 812-816.

[11]. Vaghbhatta. Angavibhagam shariram Adhyaya. In: Gupta AD, editors. Astanga Sangraha. Revised edition. Varanasi (India): Chaukambha Krishnadas Academy; 2016. p. 297-308.

[12]. Karampinos, Dimitrios C et al. "Quantitative MRI and spectroscopy of bone marrow." Journal of magnetic resonance imaging : JMRI vol. 47,2 (2018): 332353. doi:10.1002/jmri.25769

[13]. Hall JE, Guyton AC. Cardiovascular Physiology. In: Vaz M, editors. Textbook of medical physiology. 2nd ed. New Delhi (India): Elseveir; 2018. p. 171-172.
[14]. Dalhan. Doshadhatumalakshyavriddhi vigyaniyam adhyaya. In: Prasad BB, editors. Nibandha Sangraha on Sushrut Samhita. Revised edition. New Delhi (India): Rastriya ayurveda vidyapeeth; 2002. p.156159.

[15]. Hall JE, Guyton AC. Blood and its constituents. In: Vaz M, editors. Textbook of medical physiology. 2nd ed. New Delhi (India): Elseveir; 2018. p. 139-141.

[16]. Vaghbhatta. angvibhagiya Adhyaya. In: Gupta AD, editors. Astanga Sangraha. Revised edition. Varanasi (India): Chaukambha Krishnadas Academy; 2016. p. 301.

[17]. Sperm made from bone marrow [Internet]. [cited 2021 Feb 4]. Available from: https:// www.irishtimes.com/news/sperm-made-from-bonemarrow-1.805656.

How to cite this article: Ritesh, Manjry Anshumala Barla, Rakesh Roushan. Concept of Majja Dhatu of Ayurveda in Perspective of Bone Marrow: A Review. Int J Intg Med Sci 2021;8(3):982-988. DOI: 10.16965/ ijims.2021.108 